\title{
Correction to: Muscle Stem Cells
}

\section{Eusebio Perdiguero and DDW Cornelison}

\section{Correction to:}

\section{Eusebio Perdiguero and DDW Cornelison (eds.), Muscle Stem Cells:}

Methods and Protocols, Methods in Molecular Biology, vol. 1556, https://doi.org/10.1007/978-1-4939-6771-1

1) A typographical error in the title for chapter 4 had appeared on SpringerLink and Springer.com websites, and has been corrected to: "Isolation, Culture, and Immunostaining of Skeletal Muscle Myofibers from Wildtype and Nestin-GFP Mice as a Means to Analyze Satellite Cells" on these websites.

2) A wrong video was posted for Chapter 16 "Methods for Observing and Quantifying Muscle Satellite Cell Motility and Invasion In Vitro", on Springerlink and has been corrected now.

\footnotetext{
The updated online version of these chapters can be found at https://doi.org/10.1007/978-1-4939-6771-1_4 https://doi.org/10.1007/978-1-4939-6771-1_16 https://doi.org/10.1007/978-1-4939-6771-1
} 